\title{
NASIONALISASI PERUSAHAAN MODAL ASING: \\ Ide Normatif Pengaturan Hukumnya dalam UU No. 25 Tahun 2007 dan Relevansinya dengan Konsep Negara Hukum Kesejahteraan Pancasila dalam UUD NRI Tahun 1945
}

\author{
Muhammad Syaifuddin ${ }^{1}$
}

\begin{abstract}
Abstrak
Pengaturan hukum nasionalisasi perusahaan modal asing dalam UU No. 25 Tahun 2007 merupakan upaya Indonesia mengendalikan isu globalisasi ekonomi dalam penanam modal, yang didasarkan atas ide normatif mewujudkan kedaulatan ekonomi dan politik Indonesia, untuk mempercepat pembangunan ekonomi nasional, yang mengedepankan potensi bangsa dan negara dengan tidak menutup diri pada masuk masuknya modal asing dalam rangka mewujudkan kesejahteraan rakyat Indonesia, sehingga ide normatif dimaksud, mempunyai relevansi dengan konsep Negara Hukum Kesejahteraan Pancasila dalam UUD NRI Tahun 1945, yang membolehkan nasionalisasi perusahaan modal asing, dengan persyaratan kondisional, tujuan dan prosedural. Selanjutnya, asas-asas hukum yang merefleksikan ide normatif pengaturan hukum nasionalisasi perusahaan modal asing dalam UU No. 25 Tahun 2007 tersebut adalah asas kepastian hukum, asas keterbukaan, asas akuntabilitas, asas perlakuan yang sama dan tidak membedakan asal, dan asas kemandirian, yang dikonkritisasi hukum dalam UU No. 25 Tahun 2007 jis. UU No. 30 Tahun 1999 yang membolehkan nasionalisasi perusahaan modal asing, dengan persyaratan, yaitu: 1. kepentingan negara menghendaki; 2. berdasarkan undang-undang; 3. disertai kompensasi sesuai dengan asas-asas hukum internasional; 4. diselesaikan secara nonlitigasi dalam kerangka hukum alternatif penyelesaian sengketa; dan 5. diselesaikan melalui arbitrase, jika alternatif penyelesaian sengketa tidak berhasil.
\end{abstract}

Kata Kunci: Nasionalisasi, Perusahaan Modal Asing, Negara Hukum Kesejahteraan Pancasila.

1 Penulis adalah Dosen Fakultas Hukum Universitas Sriwijaya. Alamat kontak: aalaw_firm@yahoo.com. 


\begin{abstract}
Foreign direct investment which has positive and negative impact in this economic globalization era creates normative idea which stipulating the nationalization of the foreign investment corporation in Indonesian Law No.25 Year 2007. Those ideas are Performing the economic and political sovereignty in Indonesia, which impressed the nation potential and still open the possibility for the coming of foreign investment in order to committing the Indonesian public welfare. Therefore the mention normative idea, has relevancy to the Pancasila Welfare State Law which stated in Indonesia Fundament Regulation No 1945 that allowed the nationalization with its conditional, purpose and procedural conditions. The nationalization of foreign investment corporation in law No.25 of 2007 is the law certainty principal, disclosure principal, accountability principal, equal treatment which not differentiate the origin principle, autonomy principle and harmony principle which embodied in Regulation No 2005 year 2007 jis. Regulation No 30. 1999, which permitting the nationalization of foreign corporation with some conditions i.e. 1. National interest allowed, 2. Based on regulation, 3. With proportional compensation used international regulations, 4. Settled by non litigation or in alternatife disputes settlement procedure and 5 solved by arbitration, if other alternative dispute resolution is unsuccessful.
\end{abstract}

Keyword: Nationalization, Foreign Investment Corporation, Pancasila Welfare Law State

\title{
I. Pendahuluan
}

Nasionalisasi perusahaan modal asing adalah satu di antara beberapa standar kebijakan penanaman modal ${ }^{2}$ yang harus diatur secara jelas di suatu negara tempat penanaman modal (host country). Di Indonesia, nasionalisasi perusahaan modal asing diatur hanya dalam satu pasal, yaitu Pasal 7 Undang-Undang Nomor 25 Tahun 2007 tentang Penanaman Modal (selanjutnya disingkat UU No. 25 Tahun 2007), ${ }^{3}$

${ }^{2}$ Standar kebijakan penanaman modal lainnya, khususnya penanaman modal asing, antara lain, ialah: pelayanan perizinan yang jelas (admission), keterbukaan informasi mengenai aturan hukum penanaman modal, perlakuan terhadap penanaman modal, konsesi, transfer dana, dan penyelesaian sengketa. Keith S. Rossen, dalam Fakultas Ekonomi Universitas Airlangga. 2006. Jawaban dan Masukan RUU Penanaman Modal, No. 1310/J.3.1.12/LL.2006, tanggal 21 September 2006. 
yang merupakan wujud normatif dari kesukarelaan Pemerintah Indonesia untuk membatasi haknya sebagai negara yang berdaulat, dengan cara memperketat persyaratan untuk menasionalisasi perusahaan modal asing.

Pemerintah Indonesia menyadari bahwa di tengah perdebatan tentang penanaman modal asing yang berdampak positif ${ }^{4}$ dan berdampak negatif, ${ }^{5}$ pengaturan hukum nasionalisasi perusahaan modal asing dalam UU No. 25 Tahun 2007 diharapkan dapat mengakomodasi kepentingan Pemerintah Indonesia untuk menarik penanaman modal asing guna mendukung pembangunan ekonomi, tanpa mengabaikan potensi penanaman modal dalam negeri. ${ }^{6}$

Pembentukan UU No. 25 Tahun 2007 merupakan respon Indonesia terhadap isu dalam proses globalisasi ekonomi, yaitu liberalisasi dan kapitalisasi dalam penanaman modal, ${ }^{7}$ yang didukung secara aturan dan kelembangaan oleh WTO. ${ }^{8}$

${ }^{3}$ Dengan berlakunya UU No. 25 Tahun 2007, termasuk Pasal 7, maka undang-undang yang berlaku sebelumnya, yaitu Undang-Undang Nomor 1 Tahun 1967 tentang Penanaman Modal Asing jo. Undang-Undang Nomor 11 Tahun 1970, termasuk Pasal 21 dan 22 yang mengatur nasionalisasi perusahaan modal asing di Indonesia, tidak berlaku lagi.

${ }^{4}$ Djisman Simanjuntak, dkk., "Naskah Akademik Rancangan Undang-Undang Penanaman Modal", (Badan Pembinaan Hukum Nasional-Departemen Hukum dan Hak Asasi Manusia, Jakarta, 2006), hal. 9, menegaskan dampak penanaman modal, termasuk penanaman modal asing, yaitu: a. menciptakan lapangan kerja dan mengurangi pengangguran; b) meningkatkan kesejahteraan pekerja dengan meningkatkan intensitas modal, sehingga dapat mengejar ketinggalan Indonesia; c) mengimbangi keusangan cepat karena penggunaan yang salah dan perawatan yang buruk; d) mengimbangi pengurasan modal alami dan memburuknya kualitas lingkungan hidup; dan e) menghadapi lonjakan kebutuhan modal, karena revolusi teknologi.

${ }^{5}$ Huala Adolf, "Perjanjian Penanaman Modal dalam Hukum Perdagangan Internasional (WTO)", (Jakarta: PT. RajaGrafindo Persada, 2004), hal. 7-8, menjelaskan dampak negatif penanaman modal asing, yaitu: a) dapat menimbulkan sengketa dengan negara penerima atau dengan penduduk asli setempat; b) dapat mengontrol atau mendominasi perusahaan-perusahaan lokal; c) dapat memengaruhi kebijakan ekonomi, bahkan kebijakan politis dari negara penerima; d) mengembalikan keuntungan dari kegiatan bisnisnya ke negara asal di mana perusahaan induknya berada, sehingga mengurangi cadangan persediaan mata uang asing (foreign exchange reserves); f) merusak lingkungan di sekitar lokasi usahanya di negara penerima, karena telah menggunakan zat-zat berbahaya yang membahayakan lingkungan atau menerapkan teknologi yang tidak atau kurang memerhatikan kelestarian lingkungan; dan g) merusak aspek-aspek positif dari penanaman modal itu sendiri, misalnya, praktik kegiatan usahanya yang bersifat restriktif (restrictive business practices).

${ }^{6}$ Perhatikan Konsiderans "Menimbang" huruf c UU No. 25 Tahun 2007.

7 Hira Jhamtani, "WTO dan Penjajahan Kembali Dunia Ketiga", Penyunting Roem Topatimasang, (Yogyakarta: INSISTPress, 2005), hal. 23, menjelaskan bahwa globalisasi ekonomi 
Proses globalisasi ekonomi yang bersemangat liberalisasi dan kapitalisasi dalam penanaman modal tidak dapat dicegah, tetapi dapat dikendalikan oleh Pemerintah Indonesia, dengan menggunakan UU No. 25 Tahun 2007 sebagai instrumen pengedaliannya, baik dalam makna pencegahan (prevenstif) maupun penindakan (represif), yang harus dibentuk dengan mengacu kepada Pancasila sebagai weltanschauung, ${ }^{9}$ yang terkandung dalam Undang-Undang Dasar Negara Republik Indonesia Tahun 1945 (selanjutnya disingkat UUD NRI Tahun 1945) sebagai konstitusi ekonomi Indonesia ${ }^{10}$ yang memuat konsep Negara Hukum Kesejahteraan Pancasila.

Nasionalisasi perusahaan modal asing merupakan bentuk pengendalian (dalam makna penindakan atau represif) dampak negatif penanaman modal asing dalam proses globalisasi ekonomi di Indonesia menggunakan instrumen hukum berupa UU No. 25 Tahun 2007. Sehubungan dengan itu, penting untuk dikaji tiga persoalan hukum, yaitu: pertama, apakah ide normatif pengaturan hukum nasionalisasi

saat ini sering disebut sebagai "corporate driven globalization" (globalisasi yang dikendalikan oleh korporasi), yang menurut Hira Jhamtani, menutupi suatu persekongkolan raksasa untuk memerdagangkan bumi beserta isinya antara perusahaan-perusahaan multinasional dengan pemerintah negara-negara maju dan lembaga-lembaga internasional, antara lain WTO, yang tujuan akhirnya adalah penjajahan kembali dunia ketiga.

${ }^{8}$ Fritjof Capra, "The Hidden Connections, Strategi Sistemik Melawan Kapitalisme Baru", (Yogyakarta: Penerbit Jalasutra, 2004), hal. 145, mengungkapkan bahwa aturan-aturan ekonomi yang dibuat oleh WTO nyata-nyata tak dapat berkelanjutan dan menghasilkan banyak konsekuensi fatal yang saling berhubungan-disintegrasi sosial, kemacetan demokrasi, makin pesat dan luasnya kerusakan lingkungan, penyebaran penyakit-penyakit baru dan meningkatnya kemiskinan serta keterasingan.

9 Siswono Yudohusodo, Konsepsi Negara Kesejahteraan dalam Pembangunan Sistem Kenegaraan Indonesia, Makalah, Disampaikan pada Seminar Nasional dalam Rangka Dies Natalis ke-40 Universitas Pancasila, Jakarta, 7 Desember 2006, hal. 4, menjelaskan bahwa setiap negara bangsa membutuhkan weltanschauung atau landasan filosofis yang menjadi dasar negara dan ideologi dari negara. Atas dasar landasan filosofis itu, disusunlah visi, misi dan tujuan negara. Tanpa itu, negara bergerak tanpa pedoman.

${ }^{10}$ Jimly Asshiddiqie, "Konstitusi Ekonomi", (Jakarta: PT. Kompas Media Nusantara, 2010), hal. xi, menjelaskan bahwa setelah reformasi konstitusi, UUD 1945 lebih banyak memuat ketentuanketentuan mengenai hak asasi manusia dan prinsip-prinsip demokrasi seperti dalam tradisi negaranegara liberal. Akan tetapi, pada saat yang bersamaan, UUD 1945 pascareformasi juga memuat lebih tegas ketentuan tentang perekonomian dan kesejahteraan sosial seperti dalam tradisi negara-negara sosialis. Dengan demikian, dapat dikatakan bahwa UUD 1945 tidak semata-mata merupakan dokumen politik, tetapi juga merupakan dokumen ekonomi. UUD 1945 bukan hanya konstitusi politik, tetapi juga konstitusi ekonomi. 
perusahaan modal asing dalam UU No. 25 Tahun 2007?; kedua, bagaimanakah relevansi ide normatif pengaturan hukum nasionalisasi perusahaan modal asing dalam UU No. 25 Tahun 2007 dengan dengan konsep Negara Hukum Kesejahteraan Pancasila dalam UUD NRI Tahun 1945?; dan ketiga, apakah asas-asas hukum yang merefleksikan ide normatif pengaturan hukum nasionalisasi perusahaan modal asing dan bagaimanakah konkritisasi hukumnya dalam UU No. 25 Tahun 2007 dan aturan hukum positif terkait lainnya?

\section{Pembahasan}

\section{Ide Normatif Pengaturan Hukum Nasionalisasi Perusahaan Modal Asing dalam UU No. 25 Tahun 2007}

UU No. 25 Tahun 2007 (vide Bab 1 Ketentuan Umum, Pasal 1) tidak memuat konsep nasionalisasi secara khusus dan konkrit. Namun, berdasarkan penafsiran gramatikal terhadap Pasal 7 ayat (1) dan ayat (2) UU No. 25 Tahun 2007 yang memuat rumusan normatif dengan menggunakan kata "atau pengambilalihan hak kepemilikan penanaman modal" setelah kalimat "tindakan nasionalisasi", maka dapat dipahami secara konseptual bahwa nasionalisasi perusahaan modal asing adalah "pengambilalihan hak kepemilikan penanaman modal asing".

Penanaman modal asing adalah suatu kegiatan usaha yang dilakukan oleh penanam modal asing dengan cara mendirikan perusahaan modal asing di Indonesia, ${ }^{11}$ yang menurut Pasal 5 ayat (2) UU No. 25 Tahun 2007 harus berbentuk badan hukum perseroan terbatas (PT. $)^{12}$ sebagaimana diatur dalam

11 Penanaman modal asing yang diatur dalam UU No. 25 Tahun 2007 adalah penanaman modal asing langsung (foreign direct investment), dalam arti penanam modal asingnya mendirikan dan mengelola perusahaan modal asing secara langsung di Indonesia, sehingga penanaman modal asing itu bertanggung jawab sepenuhnya atas risiko yang timbul dari pendirian dan pengelolaan perusahaan modal asing dimaksud. Selain penanaman modal asing secara langsung, juga terdapat bentuk/cara penanaman modal asing tidak langsing (fortpolio investment) yang diatur dalam Undang-Undang Nomor 8 Tahun 1995 tentang Pasar Modal, dalam arti penanam modal asing tidak mendirikan dan mengelola secara langsung perusahaan, melainkan membeli saham (dan obligasi) dalam jumlah yang terbatas dari suatu perusahaan yang telah terdaftar dan menjual efek (saham, obligasi, dll.) di pasar modal Indonesia (PT. Bursa Efek Indonesia), sehingga penanam modal asing itu bertanggung jawab terbatas (tidak sepenuhnya) atas risiko yang timbul dari pendirian dan pengeloaan perusahaan dimaksud. 
Undang-Undang Nomor 40 tahun 2007 tentang Perseroan Terbatas (selanjutnya disingkat UU No. 40 Tahun 2007), ${ }^{13}$ yang didirikan menurut hukum Indonesia dan berdomisili di Indonesia. ${ }^{14}$

Penanam modal asing mempunyai hak kepemilikan atas perusahaan modal asing di mana modal asingnya ditanam. Jika kemudian Pemerintah Indonesia, berdasarkan Pasal 7 UU No. 25 Tahun 2007, melakukan nasionalisasi, dalam arti melakukan pengambilalihan hak kepemilikan penanaman modal asing disertai kompensasi atau ganti rugi kepada penanam modal asingnya, maka secara yuridis (akan) berakibat hukum, yaitu: pertama, Pemerintah Indonesia berkedudukan sebagai pemilik/pemegang modal dan saham menggantikan penanam modal asing yang bersangkutan: kedua, status dan bentuk badan hukum perusahaan modal asingnya berubah dari perseroan terbatas swasta menjadi badan usaha milik negara (selanjutnya disingkat BUMN) ${ }^{15}$ yang dapat berbentuk hukum perusahaan perseroan ${ }^{16}$ atau perusahaan umum ${ }^{17}$

${ }^{12}$ Berbeda dengan penanaman modal asing, untuk penanaman modal dalam negeri menurut Pasal 5 ayat (1) UU No. 25 Tahun 2007 dapat berbentuk badan hukum, tidak berbadan hukum, atau usaha perseorangan . Jadi ada kebebasan bagi penanam modal dalam negeri untuk memilih dan menggunakan bentuk badan hukum perusahaannya, misalnya persekutuan perdata yang diatur dalam Kitab Undang-Undang Hukum Perdata, atau persekutuan firma dan persekutuan komanditer yang diatur dalam Kitab Undang-Undang Hukum Dagang, atau koperasi yang diatur dalam UndangUndang Nomor 25 Tahun 1992 tentang Perkoperasian, bahkan perusahaan perseorangan yang belum ada aturan hukum khusus dan konkrit.

${ }^{13}$ Pengertian yuridis Perseroan Terbatas menurut Pasal 1 angka 1 UU No. 40 Tahun 2007 adalah "Badan hukum yang merupakan persekutuan modal, didirikan berdasarkan perjanjian, melakukan kegiatan usaha dengan modal dasar yang seluruhnya terbagi dalam saham dan memenuhi persyaratan dalam undang-undang ini serta peraturan pelaksanaannya.

${ }^{14}$ Logika hukum dari keharusan perusahaan modal asing berbentuk hukum perseroan terbatas yang didirikan menurut hukum Indonesia dan berdomisili di Indonesia (vide Pasal 5 UU No. 25 tahun 2007) bersandar pada doktrin hukum perdata internasional yang menegaskan bahwa "hukum yang berlaku bagi badan hukum adalah hukum dari negara yang tempat badan hukum asing itu didirikan atau hukum dari negara tempat kantor pusat badan hukum itu berdomisili". Berdasarkan doktrin hukum perdata internasional ini, hukum Indonesia berlaku bagi pendirian, pengelolaan dan pengawasan perusahaan modal asing serta penyelesaian sengketa penanaman modal asing.

${ }^{15}$ Badan Usaha Milik Negara menurut Pasal 1 angka 1 UU No. 19 Tahun 2003 adalah "Badan usaha yang seluruh atau sebagian besar modalnya dimiliki oleh negara melalui penyertaan secara langsung yang berasal dari kekayaan negara yang dipisahkan".

${ }^{16}$ Perusahaan Perseroan (PT. Persero) menurut Pasal 1 angka 3 UU No. 19 Tahun 2003 adalah "Badan Usaha Milik Negara yang berbentuk perseroan terbatas yang modalnya terbagi dalam 
sebagaimana diatur dalam Undang-Undang Nomor 19 Tahun 2003 tentang Badan Usaha Milik Negara (selanjutnya disingkat UU No. 19 Tahun 2003). Bentuk hukum perusahaan yang manakah yang akan dipilih/ditetapkan oleh Pemerintah Indonesia, sangat ditentukan oleh politik hukum ekonomi dan pilihan tujuan yang hendak diwujudkan oleh Pemerintah Indonesia melalui BUMN. ${ }^{18}$

Konsep nasionalisasi perusahaan modal asing sebagai pengambilalihan hak kepemilikan penanaman modal asing yang disertai kompensasi atau ganti rugi oleh Pemerintah Indonesia mempunyai sandaran secara doktrinal (doktrin hukum). ${ }^{19}$ Menurut P. Adriaanse, istilah nasionalisasi bermakna: pertama, konfiskasi (confiscation), yaitu tindakan pemerintah mengambilalih milik perorangan yang tidak disertai ganti rugi atau kompensasi (compensation); dan kedua eksproriasi (expropriation), yaitu tindakan pemerintah untuk mengambilalih milik perorangan yang disertai ganti rugi atau kompensasi

saham yang seluruh atau paling sedikit $51 \%$ (lima puluh satu persen) sahamnya dimiliki oleh Negara Republik Indonesia yang tujuan utamanya mengejar keuntungan".

${ }^{17}$ Perusahaan Umum (Perum) menurut Pasal 1 angka 4 UU No. 19 Tahun 2003 adalah "Badan Usaha Milik Negara yang seluruh modalnya dimiliki negara dan tidak terbagi atas saham, yang bertujuan untuk kemanfaatan umum berupa penyediaan barang dan/atau jasa yang bermutu tinggi dan sekaligus mengejar keuntungan berdasarkan prinsip pengelolaan perusahaan".

18 Sebagai BUMN, baik perusahaan perseroan maupun perusahaan umum mempunyai maksud dan tujuan umum, yaitu: 1) memberikan sumbangan bagi perkembangan perekonomian nasional pada umumnya dan penerimaan negara pada khususnya; 2) mengejar keuntungan; 3). menyelenggarakan kemanfaatan umum berupa penyediaan barang dan/atau jasa yang bermutu tinggi dan memadai bagi pemenuhan hajat hidup orang banyak; 4) menjadi perintis kegiatan-kegiatan usaha yang belum dapat dilaksanakan oleh sektor swasta dan koperasi; dan 5) turut aktif memberikan bimbingan dan bantuan kepada pengusaha golongan ekonomi lemah, koperasi, dan masyarakat (vide Pasal 2 UU No. 19 Tahun 2003). Selain tujuan umum, perusahaan perseroan mempunyai tujuan khusus, yaitu: "menyediakan barang dan/atau jasa yang bermutu tinggi dan berdaya saing kuat, serta mengejar keuntungan guna meningkatkan nilai perusahaan" (Pasal 12 UU No. 19 Tahun 2003), sedangkan perusahaan umum mempunyai tujuan khusus, yaitu: yaitu: "menyelenggarakan usaha yang bertujuan untuk kemanfaatan umum berupa penyediaan barang dan/atau jasa yang berkualitas dengan harga yang terjangkau oleh masyarakat berdasarkan prinsip pengelolaan perusahaan yang sehat" (Pasal 36 UU No. 19 Tahun 2003).

${ }^{19}$ Doktrin (ajaran) hukum adalah ajaran-ajaran dari sarjana-sarjana terkemuka mengenai hukum. Meskipun ilmu (doktrin) ini berperan membangun argumentasi hukum dalam pembentukan dan penerapan undang-undang maupun putusan hakim, tetapi sampai saat ini belum ada kesatuan pendapat mengenai kedudukannya sebagai sumber hukum, khususnya sumber hukum dalam arti formil. 
(compensation). Baik konfiskasi maupun eksproriasi dapat terjadi di segala bidang, ${ }^{20}$ termasuk di bidang penanaman modal. Hullman Panjaitan menjelaskan bahwa eksproriasi adalah pengambilalihan hak milik perorangan oleh pemerintah untuk kepentingan umum disertai ganti rugi yang adil, sedangkan nasionalisasi dilakukan dalam rangka usaha mengadakan perombakan struktural dalam masyarakat dan/atau negara, sehingga ganti rugi tidak merupakan suatu keharusan. ${ }^{21}$

Selanjutnya, S. Friedmann memahami nasionalisasi sebagai eksproriasi, yang dapat dibedakan menjadi: pertama, eksproriasi individual (individual exproriation), yang bermakna pengambilalihan hak milik perorangan, yang ditentukan secara khusus baik subjek maupun milik yang bersangkutan; dan kedua, ekpropriasi umum (general exproriation), yang bermakna pengambilalihan hak milik perorangan, yang ditentukan hanya miliknya saja, sedangkan subjeknya tidak ditentukan. Eksproriasi umum yang dilakukan dengan tujuan mengubah struktur ekonomi dan sosial suatu negara, dapat disebut sebagai nasionalisasi. ${ }^{22} \mathrm{Jadi}$, nasionalisasi perusahaan modal asing yang dikonseptualisasikan dalam UU No. 25 Tahun 2007 sebagai pengambilalihan hak kepemilikan penanaman modal asing yang disertai dengan kompensasi atau ganti rugi kepada penanam modal asingnya, adalah selaras dengan doktrin hukum internasional yang berkembang merujuk putusan-putusan pengadilan (internasional) yang ada.

Selanjutnya, ide normatif pengaturan hukum nasionalisasi dalam UU No. 25 Tahun 2007 dapat ditemukan: pertama, pada bagian konsiderans "Menimbang" huruf $b$, yang memuat pertimbangan dibentuknya UU No. 25 Tahun 2007, yaitu: "Untuk mempercepat pembangunan ekonomi nasional dan mewujudkan kedaulatan politik..." (cetak tebal oleh penulis); kedua, pada bagian Penjelasan Umum yang memuat penegasan bahwa konstitusi (vide UUD NRI Tahun 1945) mengamanatkan agar pembangunan ekonomi nasional harus berdasarkan prinsip ekonomi yang mampu menciptakan terwujudnya

\footnotetext{
1956), hal. 8 .

${ }^{20}$ P. Adriaanse, "Confiscation in Private International Law", (Martinus Nijhoff, The Hague,

${ }^{21}$ Hullman Panjaitan, "Hukum Penanaman Modal Asing", (Jakarta: Ind-Hill Co. 2003), hal. 127.

${ }^{22}$ S. Friedman, "Expropriation International Law”, (London: Stevens \& Sons Ltd., 1953), hal. 5 .
} 
kedaulatan ekonomi Indonesia" (cetak tebal oleh Penulis); dan ketiga, pada Pasal 3 ayat (1) huruf i yang mengandung "asas kemandirian" yang merupakan "asas hukum penanaman modal yang dilakukan dengan tetap mengedepankan potensi bangsa dan negara (cetak tebal oleh Penulis) dengan tidak menutup diri pada masuk masuknya modal asing demi terwujudnya pertumbuhan ekonomi". Jadi, penanaman modal asing, dalam perspektif UU No. 25 Tahun 2007, dimanfaatkan untuk mendukung pembangunan ekonomi nasional yang mengedepankan potensi bangsa dan negara sendiri, dalam rangka mewujudkan kesejahteraan rakyat Indonesia, tanpa mengabaikan kedaulatan ekonomi dan kedaulatan politik Indonesia.

Suatu negara yang berdaulat, termasuk Indonesia, mempunyai suatu pemerintahan yang berkuasa mengurus semua urusan kenegaraan, termasuk urusan ekonomi dan politik menggunakan semua alat-alat kenegaraan di bidang ekonomi dan politik. Menurut Abu Daud Busroh dan Abubakar Busro, berdaulat atau soverein itu adalah "kekuasaan yang tertinggi karena tidak berasal dari dan tidak bergantung pada kekuasaan lainnya". ${ }^{23}$ Kedaulatan yang dimiliki suatu negara, termasuk Indonesia, memberikan hak untuk melaksanakan yuridiksi eksklusif di wilayahnya yang merupakan konsep fundamental dalam hukum internasional. ${ }^{24}$ Dalam kaitannya dengan wilayah ini, menurut Malcolm N. Shaw, kedaulatan mempunyai tiga ciri yang sangat penting dimiliki oleh suatu negara, yaitu:

a. kedaulatan merupakan suatu prasyarat hukum untuk adanya suatu negara;

b. kedaulatan menunjukkan negara tersebut merdeka yang sekaligus juga merupakan fungsi dari suatu negara;

c. kedaulatan menimbulkan juridiksi, yaitu kekuasaan atau kompetensi hukum negara terhadap orang, benda atau peristiwa (hukum), yang merefleksikan prinsip dasar kedaulatan negara, kesamaan derajat negara dan prinsip tidak campur tangan, yang dapat mengubah, menciptakan atau mengkahiri suatu hubungan atau kewajiban hukum. ${ }^{25}$

\footnotetext{
${ }^{23}$ Abu Daud Busroh dan Abubakar Busro, "Asas-asas Hukum Tata Negara", (Jakarta: Ghalia Indonesia, 1991), hal. 126.

${ }^{24}$ D.P. O'Connell, "International Law", (London: Stevens and Sons, 1970), hal. 403.

${ }^{25}$ Malcolm N. Shaw, "International Law”, (London: Butterworths, 1986), hal. 238 dan 342.
} 
Bersandar pada makna kedaulatan negara sebagaimana dijelaskan oleh ahli-ahli hukum di atas, dapat dipahami bahwa jika potensi ancaman penanaman modal asing terhadap kedaulatan negara Indonesia di bidang ekonomi dan politik menjadi riil, dalam arti Pemerintahan Indonesia tidak lagi berdaulat untuk mengurus urusan ekonomi dan politik menggunakan alat-alat kenegaraan yang ada, yang tercermin dari adanya dominasi perusahaanperusahaan modal asing dalam stuktur ekonomi nasional dan intervensi serta determinasi perusahaan-perusahaan modal asing tersebut dalam penentuan orientasi pembangunan ekonomi dan politik nasional, yang mensubordinasi ekonomi dan politik nasional dengan semangat mengakomodasi kepentingan ekonomi kapitalistik dari para penanam modal asing dan kepentingan politik ekonomi neokolonialistik dari negara-negara maju asal para penanam modal asing tersebut, sehingga menciptakan struktur ekonomi yang berkemakmuran bagi penanam modal asingnya tetapi tidak berkeadilan sosial bagi sebagian besar rakyat Indonesia, maka perlu dilakukan upaya menegakkan kembali kedaulatan negara di bidang ekonomi dan politik dimaksud, dengan cara melakukan perubahan struktur ekonomi dan sosial dalam negara dan/atau masyarakat, yang secara strategis dilaksanakan dengan cara nasionalisasi perusahaan modal asing.

\section{Relevansi Ide Normatif Pengaturan Hukum Nasionalisasi Perusahaan Modal Asing dalam UU No. 25 Tahun 2007 dengan Konsep Negara Hukum Kesejahteraan Pancasila dalam UUD NRI Tahun 1945}

Ide normatif pengaturan hukum nasionalisasi perusahaan modal asing dalam UU No. 25 Tahun 2007 sebagaimana diuraikan di atas, mempunyai relevansi dengan Konsep Negara Hukum Kesejahteraan Pancasila dalam UUD NRI Tahun 1945. Negara Hukum Kesejahteraan Pancasila yang dikonseptualisasikan dalam UUD NRI Tahun $1945,{ }^{26}$ adalah negara yang

${ }^{26}$ Konsep Negara Hukum Kesejahteraan Pancasila sebenarnya dapat ditelusuri dalam konstitusi ekonomi yang pernah berlaku di Indonesia, seperti Konstitusi Republik Indonesia Serikat 1945 (vide Alinea ke-4 Mukadimah dan Pasal 1 ayat (1)), UUD Sementara 1950 (vide Alinea ke-4 Mukadimah dan Pasal 1 ayat (1)), dan UUD 1945 sebelum Perubahan (vide Penjelasan Umum), yang dipertegaskan kembali dalam UUD NRI Tahun 1945 setelah Perubahan (vide Pembukaan dan Pasal 1 ayat (3)). Jadi, konstitusi ekonomi Indonesia (UUD) yang pernah ada dalam sistem ketatanegaraan 
didirikan dan diselenggarakan berdasarkan atas Pancasila sebagai ideologi negara dan UUD NRI Tahun 1945 sebagai konstitusi negara, yang dijabarkan dalam berbagai peraturan hukum dan peraturan kebijakan yang secara formal dibentuk secara demokratis dan secara materil menjamin kepastian, keadilan dan kemanfaatan hukum, yang bertujuan mewujudkan kesejahteraan dalam arti seluas-luasnya bagi sebanyak-banyaknya rakyat Indonesia, dalam rangka menjunjung tinggi harkat dan martabat kemanusiaan manusia Indonesia sebagai makhluk Tuhan yang Maha Esa.

Konsep Negara Hukum Kesejahteraan Pancasila mengandung unsur-unsur yang terkandung dalam konsep rechtstaat ${ }^{27}$ dan rule of law. ${ }^{28}$ Namun, perbedaan prinsipilnya terletak pada landasan kefilsafatan kenegaraannya, yaitu Negara Hukum Kesejahteraan Pancasila berbasis pada filsafat Pancasila yang menyerasikan kepentingan individualistik-materialistik dan kepentingan kolektivistik-spiritualistik, sedangkan rechtstaat dan rule of law berbasis pada filsafat liberalistik yang mengutamakan kepentingan individualistikmaterialistik, sehingga konsep Negara Hukum Kesejahteraan Pancasila lebih utuh secara substantif dalam memaknai hakaket manusia sebagai makhluk sosial (warga masyarakat) dan makhluk ciptaan Tuhan yang Maha Esa.

Konsep Negara Hukum Kesejahteraan Pancasila dalam UUD NRI Tahun 1945, dalam perspektif Teori Negara Hukum merupakan negara hukum materiil (negara hukum dalam pengertian luas) atau "negara hukum modern", yang tugasnya bukan hanya menjaga keamanan dan ketertiban semata, tetapi juga berperan aktif mensejahterakan rakyatnya.

Indonesia, bahkan berlaku saat ini secara tegas menyatakan bahwa Indonesia sebagai Negara Hukum Kesejahteraan Pancasila.

${ }^{27}$ Rechstaat adalah konsep negara hukum yang dibangun dan dikembangkan secara revolusioner, yang bertumpu pada sistem hukum Eropa Kontinental (civil law). Menurut F.J. Stahl, suatu negara hukum haruslah memenuhi empat unsur penting, yaitu: 1) pengakuan dan perlindungan hak asasi manusia; 2) adanya pembagian kekuasaan; 3) pemerintahan haruslah berdasarkan undangundang; dan 4) adanya peradilan administrasi. Perhatikan Azhary. 1995. Negara Hukum Indonesia (Analisis Yuridis tentang Unsur-unsurnya), UI-Press, Jakarta, hal. 49.

${ }^{28}$ Rule of law adalah konsep negara hukum yang dibangun dan berkembang secara evolusioner yang bertumpu pada sistem hukum Anglo Saxon (common law). Menurut A.V. Dicey, suatu negara hukum mengandung tiga unsur penting, yaitu: 1) supremacy of law (supremasi hukum); 2) equality before the law (persamaan di hadapan hukum); 3) human rights (hak-hak asasi manusia). Perhatikan Ibid., hal. 39-42. 
Negara hukum modern mempunyai ciri-ciri atau karakteristik negara hukum kesejahteraan sebagaimana diuraikan oleh Bachsan Mustafa, sebagai berikut:

a. Negara mengutamakan kepentingan rakyat (welfare state);

b. Negara campur tangan dalam semua lapangan kehidupan masyarakat;

c. Negara menganut sistem ekonomi yang lebih dipimpin oleh pemerintah pusat, bukan ekonomi liberal;

d. Negara menyelenggarakan kepentingan umum;

e. Negara menjaga keamanan dalam arti luas di segala lapangan kehidupan masyarakat. $^{29}$

Secara substantif, konsep Negara Hukum Kesejahteraan Pancasila menurut UUD NRI 1945, tentu saja mengandung jiwa dan semangat Pancasila, yang oleh Philipus M. Hadjon disebutnya "jiwa dan isi Negara Hukum Pancasila", yaitu:

a. Negara menghendaki keserasian hubungan antara pemerintah dan rakyat berdasarkan asas kerukunan;

b. Terjalinnya hubungan fungsional yang proporsional antara kekuasaankekuasaan negara;

c. Penyelesaian sengketa secara musyawarah; sedangkan peradilan merupakan sarana terakhir;

d. Menekankan hak asasi manusia yang seimbang dengan kewajiban asasi manusia. $^{30}$

Memerhatikan dan mengelaborasi ide dasar, unsur-unsur, dan karakteristik Negara Hukum Kesejahteraan Pancasila yang dikonseptualisasikan dalam UUD NRI 1945 dengan ide normatif pengaturan hukum nasionalisasi perusahaan modal asing dalam UU No. 25 Tahun 2007 sebagaimana dijelaskan di atas, dapat dipahami bahwa konsep Negara Hukum Kesejahteraan Pancasila membolehkan nasionalisasi perusahaan modal asing dimaksud, tetapi harus memenuhi persyaratan, sebagai berikut: hal. 114 .

${ }^{29}$ Bachsan Mustafa, "Pokok-pokok Hukum Administrasi Negara", (Bandung: Alumni, 1998), 1987), hal. 84.

${ }^{30}$ Philipus M. Hadjon, "Perlindungan Hukum bagi Rakyat Indonesia", (Surabaya: Bina Ilmu, 
a. Persyaratan kondisional:

1) Negara dalam realitasnya tidak lagi berdaulat secara ekonomi dan politik, yang tercermin dari dominasi perusahaan-perusahaan modal asing dalam stuktur ekonomi nasional yang dalam berbagai situasi dan kondisi melakukan intervensi secara determinan, sehingga mengubah orientasi pembangunan ekonomi nasional dari pembangunan ekonomi nasional yang berorientasi kesejahteraan rakyat menjadi pembangunan ekonomi nasional yang berorientasi kesejahteraan kaum penanam/pemilik modal asing;

2) Kepentingan ekonomi nasional menjadi subordinasi dari kepentingan ekonomi global, sehingga menciptakan struktur sosial-ekonomi yang sangat timpang, dalam arti memberikan kemakmuran bagi para penanam modal asing dan negara-negara asal para penanam modal asingnya, tetapi tidak berkeadilan sosial bagi sebagian besar rakyat Indonesia;

b. Persyaratan tujuan

1) Menegakkan kembali kedaulatan ekonomi dan kedaulatan politik, dengan cara melakukan perubahan struktur ekonomi dan sosial dalam negara dan/atau masyarakat yang tidak didominasi dan diintervensi secara determinan oleh perusahaan-perusahaan modal asing;

2) Mewujudkan kesejahteraan dalam arti seluas-luasnya bagi sebanyakbanyaknya rakyat Indonesia, dalam rangka menjunjung tinggi harkat dan martabat kemanusiaan manusia Indonesia sebagai makhluk Tuhan yang Maha Esa.

c. Persyaratan prosedural

1) Dilakukan berdasarkan peraturan hukum yang berkepastian, berkeadilan dan berkemanfaatan;

2) Dilakukan sesuai dengan asas-asas dan norma-norma hukum internasional yang diakui dan berlaku di negara-negara yang beradab.

3) Diselesaikan secara musyawarah untuk mencapai mufakat, sedangkan pengadilan merupakan alternatif terakhir jika penyelesaian sengketa secara musyawarah tidak mencapai mufakat. 


\section{Asas-asas Hukum Nasionalisasi Perusahaan Modal Asing dan Konkritisasi Hukumnya dalam UU No. 25 Tahun 2007 dan Aturan Hukum Positif Terkait Lainnya}

Keberadaan asas hukum, menurut Soedjadi, adalah conditio sine quanon bagi norma hukum, karena mengandung nilai-nilai moral dan etis, yang mengarahkan pembentukan hukum yang memenuhi nilai-nilai filosofis berintikan rasa keadilan dan kebenaran, nilai-nilai sosiologis yang sesuai dengan tata nilai budaya yang berlaku di masyarakat, serta nilai-nilai yuridis yang sesuai hukum yang berlaku. ${ }^{31}$ Pengaturan hukum nasionalisasi perusahaan modal asing dalam UU No. 25 Tahun 2007 didasarkan atas asasasas hukum penyelenggaraan penanaman modal sebagaimana termuat dalam Pasal 3, terutama: asas kepastian hukum, ${ }^{32}$ asas keterbukaan, ${ }^{33}$ asas akuntabilitas, ${ }^{34}$ asas perlakuan yang sama dan tidak membedakan asal, ${ }^{35}$ dan asas kemandirian. ${ }^{36}$ 1999), hal. 68.

${ }^{31}$ Soejadi, "Pancasila sebagai Sumber Tertib Hukum Indonesia", (Jakarta: Lukman Offset,

${ }^{32}$ Asas kepastian hukum, yaitu asas dalam negara hukum yang meletakkan hukum dan ketentuan peraturan perundang-undangan sebagai dasar dalam setiap kebijakan dan tindakan dalam bidang penanaman modal (vide Pasal 3 huruf a UU No. 25 Tahun 2007).

${ }^{33}$ Asas keterbukaan, yaitu asas yang terbuka terhadap hak masyarakat untuk memperoleh informasi yang benar, jujur, dan tidak diskriminatif tentang kegiatan penanaman modal (vide Pasal 3 huruf b UU No. 25 Tahun 2007).

${ }^{34}$ Asas akuntabilitas, yaitu yaitu asas yang menentukan bahwa setiap kegiatan dan hasil akhir dari penyelenggaraan penanaman modal harus dipertanggungjawabkan kepada masyarakat atau rakyat sebagai pemegang kedaulatan tertinggi negara sesuai dengan ketentuan peraturan perundangundangan (vide Pasal 3 huruf c UU No. 25 Tahun 2007).

${ }^{35}$ Asas perlakuan yang sama dan tidak membedakan asal yaitu asas perlakuan pelayanan nondiskriminasi berdasarkan ketentuan peraturan perundang-undangan, baik antara penanam modal dalam negeri dan penanam modal asing dan penanam modal dari negara asing lainnya (vide Pasal 3 huruf d UU No. 25 Tahun 2007).

${ }^{36}$ Asas kemandirian, yaitu yaitu asas penanaman modal yang dilakukan dengan tetap mengedepankan potensi bangsa dan negara dengan tidak menutup diri pada masuknya modal asing demi terwujudnya pertumbuhan ekonomi(vide Pasal 3 huruf e UU No. 25 Tahun 2007). 
Pemuatan "asas-asas hukum umum" dalam Pasal 3 UU No. 25 Tahun 2007 adalah upaya harmonisasi hukum ${ }^{37}$ penanaman modal nasional (vide UU No. 25 Tahun 2007) dengan hukum penanaman modal internasional, terutama Perjanjian WTO $^{38}$ berikut TRIM's (Agreement on Trade Related Investment Measures), sebagai lampiran yang tidak terpisahkan dari Perjanjian WTO, ${ }^{39}$ yang telah diratifikasi oleh Indonesia berdasarkan Undang-Undang Nomor 7 Tahun 1994. ${ }^{40}$ Indonesia, dalam menyelenggarakan penanaman modal, termasuk melakukan nasionalisasi perusahaan modal asing, terikat secara yuridis dengan Perjanjian WTO dan TRIMs yang memuat prinsip-prinsip

37 Harmoninasi hukum dijelaskan oleh Moh. Hasan Wargakusumah, dkk., "Perumusan Harmonisasi Hukum tentang Metodologi Harmonisasi Hukum ", (Badan Pembinaan Hukum Nasional Departemen Kehakiman, Jakarta, 1996-1997), hal. 37, yaitu "Kegiatan ilmiah untuk menuju proses pengharmonisan hukum tertulis yang mengacu baik pada nilai-nilai filosofis, sosiologis, ekonomis maupun yuridis. Pengkajian terhadap rancangan peraturan perundang-undangan, dalam berbagai aspek apakah telah mencerminkan keselarasan dan kesesuaian dengan peraturan perundang-undangan yang lain, hukum tidak tertulis yang hidup dalam masyarakat, konvensi-konvensi dan perjanjianperjanjian internasional baik bilateral maupun miltilateral yang telah diratifikasi Indonesia".

38 Perhatikan bagian konsiderans Menimbang huruf d UU No. 25 Tahun 2007, terutama kalimat: "...dalam menghadapi perubahan ekonomi global dan keikutsertaan Indonesia dalam berbagai kerjasama internasional...", yang diperjelas dalam bagian Penjelasan Umum Paragraf 10 UU No. 25 Tahun 2007, terutama kalimat "...keterlibatan Indonesia dalam berbagai kerja sama internasional yang terkait dengan penanaman modal, baik secara bilateral, regional maupun multilateral (World Trade Organization/WTO), menimbulkan berbagai konsekuensi yang harus dihadapi dan ditaati”.

${ }^{39}$ Berdasarkan pertemuan Basel (1990), para peserta setuju bahwa perjanjian hasil Putaran Uruguay harus diterima sebagai satu paket, artinya peserta tidak diperkenankan hanya memilih salah satu dari yang diinginkannya. Baca Taryana Sunandar. 1995/1996. Perkembangan Hukum Perdagangan Internasional dari GATT 1947 sampai Terbentuknya WTO, Badan Pembinaan Hukum Nasional Departemen Kehakiman, Jakarta, hal. 3.

40 Sesuai dengan Pasal 11 Konvensi Wina tahun 1986 tentang Hukum Perjanjian Internasional, pengesahan Perjanjian WTO berikut TRIMs berdasarkan UU No. 7 Tahun 1994 berakibat hukum Indonesia terikat kewajiban untuk melakukan harmonisasi hukum nasionalnya agar sesuai dengan GATT/WTO. Khusus di bidang hukum penanaman modal, maka rujukan utama harmonosasi hukumnya adalah asas-asas hukum dalam TRIMs yang merupakan lampiran yang tidak terpisahkan dari perjanjian WTO. Perhatikan Agus Broto Susilo. 1996. Dampak Yuridis, Pertimbangan Ekonomis dan Cakrawala Sosiologis Ratifikasi Agreement on Establishing the World Trade Organization oleh Indonesia, Majalah Hukum dan Pembangungan, No. 2 Tahun XXVI, hal. 97. 
hukum penanaman modal internasional, yaitu prinsip nondiskriminasi, ${ }^{41}$ prinsip most pavoured nations, ${ }^{42}$ dan prinsip national treatment. ${ }^{43}$

"Asas-asas hukum khusus" yang mendasari pengaturan hukum nasionalisasi perusahaan modal asing dikonkritisasi menjadi norma-norma hukum positif $^{44}$ dalam Pasal 7 ayat (1), ayat (2) dan ayat (3) UU No. 25 Tahun 2007, yang menentukan persyaratan yang harus dipenuhi, jika Pemerintah Indonesia akan melakukan nasionalisasi perusahaan-perusahaan modal asing di Indonesia, yaitu:

\section{a. Nasionalisasi perusahaan modal asing dilakukan karena kepentingan negara menghendaki}

Pemerintah Indonesia, bersandar pada tafsir sistematis atas konsiderans konsiderans "Menimbang" huruf $\mathrm{b}$ dan Penjelasan Umum atas UU No. 25 Tahun 2007, akan melakukan nasionalisasi perusahaan modal asing karena "kepentingan negara menghendaki", dalam arti kepentingan negara untuk memafaatkan penanaman modal asing dalam upaya mewujudkan kesejahteraan dalam makna seluas-luasnya bagi rakyat Indonesia sebanyak-banyaknya, bukan kesejahteraan ekonomi semata bagi individu atau sekelompok pemilik/penanam modal asing. Jadi, kepentingan negara bukan kepentingan individu atau kelompok atau golongan semata, melainkan kepentingan umum yang merupakan refleksi

41 Prinsip nondiskriminasi, yaitu prinsip yang mengharuskan host country untuk memperlakukan secara sama setiap penanam modal dan penanam modal di negara tempat penanaman modal dilakukan. Perhatikan Dhaniswara K. Harjono, "Hukum Penanaman Modal: Tinjauan terhadap Pemberlakuan Undang-Undang Nomor 25 Tahun 2007 tentang Penanaman Modal", (Jakarta: PT. RajaGrafindo Persada, 2007), hal. 109-110.

42 Prinsip most favoured nations, yaitu prinsip yang menuntut perlakuan yang sama dari negara host country terhadap penanam modal dari negara asing yang satu dengan penanam modal dari negara asing yang lainnya yang melakukan aktivitas penanaman modal di negara di mana penanaman modal tersebut dilakukan. Perhatikan Ibid.

${ }^{43}$ Prinsip national treatment, yaitu prinsip yang mengharuskan negara host country untuk tidak membedakan perlakuan antara penanam modal asing dengan penanam modal dalam negeri di negara host country tersebut. Perhatikan Ibid.

${ }^{44}$ Mahadi, "Falsafah Hukum suatu Pengantar", (Bandung: Citra Aditya Bakti, 1989), hal. 127, menjelaskan bahwa "Asas hukum bukan norma hukum yang dapat dipakai langsung dalam praktik, sehingga isinya perlu dibentuk lebih konkrit dan khusus". 
dari asas akuntabilitas yang mengharuskan nasionalisasi perusahaan modal asing dipertanggungjawabkan oleh pemerintah kepada masyarakat atau rakyat sebagai pemegang kedaulatan tertinggi negara sesuai dengan peraturan perundang-undangan (vide Pasal 3 huruf c UU No. 25 Tahun 2007).

Menurut Keith S. Rossen, Staf Agency for International Development, suatu negara tempat investasi ditanam (host country) tidak boleh menasionalisasi perusahaan yang berinvestasi, kecuali dengan alasan-alasan yang sah, seperti aktivitas yang terbukti merugikan keuangan negara, keamanan negara dan kesehatan masyarakat, dan dilakukan dengan cara-cara yang sah pula, seperti berdasarkan undang-undang. ${ }^{45}$ Nasionalisasi perusahaan modal asing, menurut Huala Adolf, adalah suatu pelanggaran hukum. Namun, dalam hal-hal tertentu tindakan nasionalisasi ini dapat pula sah jika dipenuhi syarat-syarat, antara lain, untuk kepentingan umum (public purpose). ${ }^{46}$

Pengadilan (The World Court) dalam kasus The Certain German Interests in Polish Upper Silesia", memutuskan bahwa "expropriation for reasons of public utility... was permissible in international law", yang artinya eksproriasi untuk kepentingan umum...diperbolehkan menurut Hukum Internasional. ${ }^{47}$ Namun, kelemahan normatifnya adalah indikator kepentingan umum sebagai alasan pemerintah suatu negara melakukan nasionalisasi perusahaan modal asing tidak ditentukan dalam aturan hukum internasional yang ada. ${ }^{48}$ Selain itu, secara doktrinal juga belum

${ }^{45}$ Keith S. Rossen, dalam Fakultas Ekonomi Universitas Airalangga, Op. Cit., hal. 2.

46 Huala Adolf, "Aspek-aspek Negara dalam Hukum Internasional", (Jakarta: PT. RajaGrafindo Persada, 1996), hal. 193-200.

${ }^{47}$ D.J. Harris, "Cases and Materials on International Law", (London: Sweet and Maxwell, 1983), hal. 425.

${ }^{48}$ Lemahnya aturan hukum internasional yang mengatur bidang penanaman modal, menurut Huala Adolf, disebabkan tidak adanya keinginan yang sungguh dari masyarakat internasional. Perhatikan, Huala Adolf. 2004. Op. Cit., hal. 3. Michael A. Geist mengungkapkan bahwa tidak adanya niat serius dari berbagai negara untuk mengatur bidang penanaman modal merupakan kendala bagi perkembangan hukum di bidang penanaman modal. Perhatikan Michael A. Geist, Toward a General Agreement on the Regulation of Foreign Direct Investment, Law \& Pol'y Int'l Bus, 1995, hal. 675. Adapun M. Somarajah berpendapat bahwa alasan utama lambatnya hukum internasional mengatur masalah penanaman modal karena tidak adanya lembaga khusus yang memformulasikan hukum 
terdapat kesepakatan di antara para ahli hukum internasional mengenai indikator kepentingan umum dimaksud.

\section{b. Nasionalisasi perusahaan modal asing dilakukan berdasarkan undang-undang}

Pemerintah Indonesia, menurut Pasal 7 ayat (1) UU No. 25 Tahun 2007, akan melakukan nasionalisasi perusahaan modal asing dengan persetujuan Dewan Perwakilan Rakyat Republik Indonesia (selanjutnya disingkat DPR RI) yang dinyatakan secara tegas dalam produk hukum berupa undang-undang. Konsekuensinya, DPR RI harus melaksanakan tugas pengawasan terhadap upaya Pemerintah Indonesia menegakkan asas kemandirian yang tetap mengedepankan potensi bangsa dan negara dalam menyelenggarakan penanaman modal (vide Pasal 3 huruf e UU No. 25 Tahun 2007).

Nasionalisasi perusahaan modal asing yang akan dilakukan berdasarkan undang-undang juga merefleksikan asas kepastian hukum (vide Pasal 3 huruf a UU No. 25 Tahun 2007). Adapun keharusan membentuk undang-undang sebagai dasar hukum nasionalisasi perusahaan modal asing di Indonesia, terkait dengan fungsi undang-undang, antara lain, yaitu: menyelenggarakan pengaturan lebih lanjut ketentuan dalam UUD NRI $1945 .^{49}$

Asas kepastian hukum (vide Pasal 3 huruf a UU No. 25 Tahun 2007) mengarahkan Pemerintah Indonesia untuk bersandar pada norma-norma hukum penyelesaian sengketa penanaman modal yang dapat diprediksi, menjamin efisiensi (dapat meminimalisasi biaya-biaya penyelesaian

internasional di bidang penanaman modal asing. Perhatikan M. Somarajah. 1994. The Law of Investment, Cambridge U.P., Cambridge, hal. 15-16.

49 Maria Farida Indrati Soeprapto, "Ilmu Perundang-Undangan: Dasar dasar dan Pembentukannya", (Yogyakarta: Penerbit Kanisius, 1998), hal. 113-115, menjelaskan bahwa fungsi undang-undang dalam perspektif ilmu perundang-undangan adalah: 1) menyelenggarakan pengaturan lebih lanjut ketentuan dalam Undang-Undang Dasar 1945 yang tegas-tegas menyebutnya; 2) pengaturan lebih lenjut secara umum aturan dasar lainnya dalam Batang Tubuh UUD 1945; 3) pengaturan lebih lanjut ketentuan dalam TAP MPR yang tegas-tegas menyebutnya; dan 4) pengaturan di bidang materi konstitusi. (Catatan penulis: fungsi undang-undang yang ke-3 saat ini telah hilang sehubungan dengan tidak diakuinya lagi TAP MPR dalam khirarki peraturan perundang-undangan di Indonesia menurut Undang-Undang Nomor 10 Tahun 2004 tentang Pembentukan Peraturan Perundang-Undangan. 
sengketa), dan mengagregasikan 50 "kepentingan negara yang menghendaki" dengan kepentingan penanam modal asing yang perusahaan modal asingnya dinasionalisasi oleh Pemerintah Indonesia secara adil, sehingga dapat mencegah tindakan diskriminasi hukum dan tindakan melanggar wewenang atau melebihi wewenang terhadap penanam modal asingnya.

Secara historis, Pemerintah Indonesia pernah melakukan nasionalisasi perusahaan-perusahaan modal asing milik penanam modal asing asal Belanda di Indonesia berdasarkan UU No. 86 Tahun 1958 tentang Nasionalisasi Perusahaan-perusahaan Milik Belanda, ${ }^{51}$ yang kemudian dijabarkan dalam peraturan pelaksana, yaitu Peraturan Pemerintah Nomor 2 Tahun 1959. ${ }^{52}$ Ini berarti bahwa UU No. 86 Tahun 1958 yang dijabarkan dalam PP No. 2 Tahun 1959 merupakan refleksi sejarah hukum nasionalisasi perusahaan modal asing di Indonesia yang bersandar pada asas kepastian hukum.

\section{c. Nasionalisasi perusahaan modal asing disertai kompensasi sesuai dengan asas-asas hukum internasional}

50 Agregasi kepentingan adalah suatu fungsi input yang memadupadankan semua kepentingan yang telah diartikulasikan. Adapun artikulasi kepentingan adalah cara yang lazim ditempuh oleh pemerintah dan anggota masyarakat agar kepentingan, kebutuhan, atau tuntutannya dapat terpenuhi dengan memuaskan. Berbagai macam kepentingan itu dapat terpenuhi oleh sistem politik jika dikemukakan secara nyata, baik melalui organisasi maupun lembaga-lembaga yang ada dalam masyarakat.Perhatikan Gabriel A. Almond, "Comparative Politics System, Process, and Policy”, (Boston: Little Brown and Company, 1978).

${ }^{51}$ Pasal 1 UU No. 86 Tahun 1958 menganut asas teritorialiteit yang memuat ketentuan bahwa "bahwa "Perusahaan-perusahaan milik Belanda yang berada di Republik Indonesia yang akan ditetapkan dengan peraturan pemerintah dikenakan nasionalisasi dan dinyatakan menjadi milik yang penuh dan bebas negara Republik Indonesia".

${ }^{52}$ PP No. 2 Tahun 1959 menjabarkan asas teritorialiteit dalam Pasal 1 UU No. 86 Tahun 1958, karena memuat ketentuan pelaksanaan bahwa perusahaan-perusahaan milik Belanda yang dikenakan nasionalisasi adalah: a. perusahaan yang seluruh atau sebagian merupakan milik perseorangan warga negara belanda dan bertempat kedudukan dalam wilayah Republik Indonesia; $b$. perusahaan milik sesuatu badan hukum hukum yang seluruhnya atau sebagian modal Perseroannya atau modal pendiriannya berasal dari perseorangan warga negara belanda dan badan hukum itu bertempat kedudukan dalam wilayah Republik Indonesia; c. perusahaan yang letaknya dalam wilayah Republiki Indonesia dan merupakan milik sesuatu badan hukum yang bertempat kedudukan dalam wilayah negara kerajaan Belanda. 
Pemerintah Indonesia, berdasarkan Pasal 7 ayat (2) UU No. 25 Tahun 2007, akan membayar kompensasi yang jumlahnya ditetapkan berdasarkan harga pasar kepada penanam modal asing yang perusahaan modal asingnya dinasionalisasi oleh Pemerintah Indonesia. Yang dimaksud dengan "harga pasar" adalah "Harga yang ditentukan menurut cara yang digunakan secara internasional oleh penilai independen yang ditunjuk oleh para pihak" (vide Penjelasan atas Pasal 7 ayat (2) UU No. 25 Tahun 2007). Adapun bentuk, jumlah dan mekanisme pembayaran kompensasi oleh Pemerintah Indonesia kepada penanam modal asing yang perusahaan modal asingnya dinasionalisasi oleh Pemerintah Indonesia tersebut mengacu pada asas-asas hukum internasional ${ }^{53}$ yang diakui dan berlaku di negara-negara yang beradab.

Substansi Pasal 7 ayat (2) UU No. 2 Tahun 2007 sebagai mana diuraikan di atas, mempunyai sandaran pemikiran hukum (teoretik) yang dikembangkan oleh L. Erades yang dikutip oleh Budiman Ginting yang memahami bahwa nasionalisasi adalah "suatu peraturan dengan mana pihak penguasa memaksakan semua atau segolongan tertentu untuk menerima (dwingt te godegen), bahwa hak-hak mereka atas semua atau beberapa macam benda tertentu beralih kepada negara". 54 Jadi, nasionalisasi ialah suatu cara peralihan hak dari pihak partikelir kepada negara secara paksa. Nasionalisasi dipahami sebagai "species" dari "genus" pencabutan hak (onteigening). Secara prinsipil, setiap ada onteigening harus disertai dengan "ganti rugi". Jika tidak disertai ganti rugi, maka yang terjadi adalah konfiskasi yang mirip dengan onteigening (pencabutan hak), tetapi tanpa disertai dengan ganti rugi, yang lazim dilakukan dalam permusuhan perang. ${ }^{55}$

53 Asas-asas hukum internasional merupakan sumber hukum yang cukup penting dalam hukum ekonomi internasional, terutama sebagai sumber yang memungkinkan sahnya kontrak-kontrak yang dilakukan oleh pihak swasta. Di samping itu, sumber hukum ini dipandang pula sebagai suatu sistem hukum yang memungkinkan untuk dipilih oleh suatu kontrak yang keabsahannya didasarkan pada hukum nasional beberapa negara. Cermati I. Seidl-Hohenveldern, General Course on Public International Law, 198 Recueil des Cours 198, 1986, hal. 60.

${ }^{54}$ L. Erades, dalam Budiman Ginting, Refleksi Historis Nasionalisasi Perusahaan Asing di Indonesia, Jurnal Equity, Vol. 12 No. 2, Agustus, 2007.

${ }^{55}$ Ibid. 
Menurut negara-negara Barat umumnya, suatu nasionalisasi perusahaan modal asing dapat dibenarkan jika disertai dengan ganti rugi yang prompt, adequate, and effective. ${ }^{56}$ Kemudian, dalam kasus The Anglo-Iranian co. tahun 1952, Pengadilan menyatakan bahwa nasionalisasi harta benda milik orang asing merupakan suatu tindakan penyitaan yang tidak sah, kecuali disertai dengan pembayaran ganti rugi yang adequate, prompt and effective. "Adequate", artinya memadai, yaitu jumlah ganti ruginya adalah mempunyai nilai yang sama dengan usahanya pada waktu menasionalisasi, ditambah dengan bunganya sampai keputusan pengadilan dikeluarkan. ${ }^{57}$ Berikutnya, dalam kasus the Chorzow Factory tahun 1928, menurut pengadilan kata "prompt", artinya cepat, yaitu pembayaran dilakukan dalam cash yang dibayarkan secepat mungkin. Selanjutnya, arti kata "effective", menurut D.J. Harris, berarti bahwa pihak yang menerima pembayaran tersebut harus dapat memanfaatkannya. Misalnya, dengan jumlah ganti rugi tersebut, ia mampu mendirikan perusahaan yang baru untuk menggantikan perusahaan lama yang telah diambilalih. $^{58}$

Sebaliknya, negara-negara berkembang berpendapat bahwa kompensasi kepada penanam modal asing yang perusahaan modal asingnya dinasionalisasi oleh pemerintah suatu negara tidak perlu adequate, prompt and effective compensation, melainkan fair compensation atau ganti rugi secara pantas. ${ }^{59}$ Jika tidak dipenuhi asas-asas

${ }^{56}$ D.J. Harris. Op. Cit. hal. 428, menjelaskan bahwa formula ini pada mulanya digunakan oleh Menteri Luar Negeri Amerika Serikat, Hull, dalam suratnya yang dikirimkan kepada Pemerintah Meksiko tahun 1940, sehubungan dengan nasionalisasi perusahaan-perusahaan modal asing milik penanam modal asing asal Amerika Serikat di Meksiko. Pembayaran ganti rugi seperti ini yang disebut juga dengan "Formula Hull", tampak dalam suratnya yang selengkapnya, sebagai berikut: "...the right to expropriate property is coupled with and conditioned on the obligation to make adequate, effective, and prompt compensation. The legality of an expropriation is in fact dependent upon the observance of this requirement".

${ }^{57}$ Ibid.

${ }^{58}$ Ibid.

${ }^{59}$ Sudargo Gautama, "Indonesia dan Arbitrase Internasional", (Bandung: Alumni, 1986), hal. 3, menjelaskan bahwa di antara ahli-ahli hukum Barat sendiri ada pula yang mendukung pendapat negara-negara berkembang dalam hal pembayaran ganti rugi sebagai akibat nasionalisasi perusahaan modal asing. Sebagai contoh, Isi Foighel berpendirian bahwa dalam hal terjadi nasionalisasi secara 
ini, maka negara itu memikul tanggung jawab internasional. ${ }^{60}$ Putusan pengadilan dalam Kasus Tembakau Bremen antara De Vereniging Deli Maatschapijen sebagai penggugat versus die Deutsch-Indonesischen Tabaks handels-G.m.b.H sebagai tergugat ternyata menerima dalil-dalil prinsip fair compensation yang diajukan oleh tergugat dan mengabaikan prinsip adequate, prompt and effective compensation yang diajukan oleh penggugat. $^{61}$

Kompensasi kepada penanam modal asing yang perusahaan modal asingnya dinasionalisasi oleh pemerintah suatu negara, menurut Schwazenberger, dapat berupa monetary compensation, yaitu ganti rugi dalam bentuk sejumlah uang, atau berupa satisfaction, yaitu ganti rugi dalam bentuk, misalnya saja, permintaan maaf yang biasanya dimintakan untuk kerugian-kerugian nonmaterial atau moral (kepribadian) suatu

besar-besaran dalam rangka perombakan struktur ekonomi sosial secara menyeluruh dari negara yang bekaas dijajah, maka tidak dapat diberikan ganti rugi yang sifatnya "prompt, adequate and effective", tetapi cukuplah diberikan ganti rugi sejumlah "lump sump", yang kemudian oleh pemerintah dan para warga negara korban nasionalisasi bersangkutan, akan dibagi-bagikan kepada mereka.

${ }^{60}$ Huala Adolf. Op. Cit., hal. 196, menegaskan bahwa pendapat ini ditarik dari pendapat Hingorani. 1984. Modern International Law, yang selengkapnya, sebagai berikut: “..., a state should give a fair compensation for the nationalised business. It need non be prompt, adequate and effective compensation as is claimed by the Western governments. If the State fails to give fair compensation, it incurs international liability in respect of foreign business".

61 Kasus ini bermula pada tahun 1958 ketika Pemerintah Indonesia menasionalisasi perusahaan-perusahaan modal asing di sektor perkebunan termabakau milik Belanda di Sumatera Utara. Dalam proses persidangan, pihak Belanda, yaitu De Vereniging Deli Maatschapijen) sebagai penggungat mendalilkan bahwa tindakan nasionalisasi oleh Pemerintah Indonesia itu tidak sah, karena tidak disertai dengan ganti rugi yang penuh, bermanfaat dan tunai (prompt, effective and adequate compensation). Dalil penggugat ini dibantah oleh pihak tergugat, yakni die Deutsch-Indonesischen Tabaks handels-G.m.b.H (perusahaan Tembakau Jerman-Indonesia) yang dibantu oleh Pemerintah Indonesia, yang mendalilkan bahwa nasionalisasi yang dilakukan oleh Pemerintah Indonesia adalah usaha untuk mengubah struktur ekonomi Indonesia dari ekonomi kolonial ke ekonomi yang bersifat nasional secara radikal, sehingga ganti ruginya cukup ganti rugin yang pantas (fair compensation). Ganti rugi yang disediakan oleh Pemerintah Indonesia sebagai pihak yang melakukan ekspropriasi nasional lain sifat dan bentuknya. Dengan Peraturan Pemerintah Nomor 9 Tahun 1959 ditentukan bahwa dari hasil penjualan hasil perkebunan tembakau persentase tertentu untuk disediakan pembayaran ganti rugi. Perhatikan Mochtar Kusumaatmadja, "Pengantar Hukum Internasional", (Bandung: Binacipta, 1982), hal. 64. 
negara. $^{62}$ Selanjutnya, monetery compensation menurut N.A. Maryan Green, dapat terdiri dari:

1) Penggantian biaya pada waktu keputusan pengadilan dikeluarkan, meskipun jumlah penggantian tersebut menjadi lebih besar dari nilai pada waktu perbuatan melawan hukum oleh negara lain terjadi (kasus The Chorzow P.C.I.J., 1928);

2) Kerugian tak langsung (indirect damages), sepanjang kerugian ini mempunyai kaitan yang langsung dengan tindakan tak sah tersebut. (Pengadilan Arbitrase antara Portugal dan Jerman tahun 1930);

3) Hilangnya keuntungan yang diharapkan, sepanjang keuntungan tersebut mungkin dalam situasi atau perkembangan yang normal (kasus The Chorzow Factory Merits);

4) Pembayaran terhadap kerugian atas bunga yang hilang karena adanya tinndakan melanggar hukum. ${ }^{63}$

Asas fair competition (ganti rugi yang pantas) yang berbasis pada doktrin hukum internasional dan putusan pengadilan (internasional) sebagaimana diuraikan di atas, selaras dengan asas "kompensasi sesuai harga pasar" menurut Pasal 7 ayat (2) UU No. 25 Tahun 2007, yang mengutamakan kepastian, keadilan dan kemanfataan, baik dari sisi Pemerintah Indonesia maupun penanam modal asing yang perushaan modal asingnya dinasionalisasi oleh Pemerintah Indonesia.

\section{d. Nasionalisasi perusahaan modal asing diselesaikan secara nonlitigasi dalam kerangka hukum alternatif penyelesaian sengketa}

Sengketa yang timbul berkaitan dengan bentuk, jumlah dan mekanisme pembayaran kompensasi kepada penanam modal asing yang perusahaan modal asingnya dinasionalisasi oleh Pemerintah Indonesia diselesaikan secara nonlitigasi dalam kerangka hukum alternatif penyelesaian sengketa.

Penyelesaian sengketa secara nonlitigasi dengan menggunakan sarana "alternatif penyelesaian sengketa" (selanjutnya disingkat APS),

${ }^{62}$ Schwanzenberger, dalam D.J. Harris. Op. Cit., hal. 397.

${ }^{63}$ N.A. Maryan Green, "International Law of Peace", (London: Mac Donald and Evans, 1982), hal. 219. 
menurut Adi Sulistiyono dan Muhammad Rustamaji, mempunyai ciri-ciri, sebagai berikut: ${ }^{64}$

1) Nilai keadilan yang dihasilkan bukan keadilan distributif, ${ }^{65}$ tetapi keadilan komutatif, yang dibicarakan bersama (pihak-pihak yang bersengketa);

2) Kedaulatan penyelesaian sengketa ada pada pihak-pihak yang bersengketa, atau masyarakat berperan dalam suatu proses penyelesaian sengketa;

3) Menggunakan pendekatan konsensus, bukan pendekatan konflik, yang dapat berupa negosiasi, mediasi, konsiliasi, perdamaian, kompensasi, dll.;

4) Mempertemukan kepentingan (interest based bargaining) ${ }^{66}$ dua pihak yang bersengketa, tidak berpijak pada kebenaran atau hak yang diyakini atau ditafsirkan oleh pihak-pihak yang bersengketa;

5) Bersandar pada nilai-nilai harmoni yang hidup di masyarakat, tidak berpatokan secara kaku pada peraturan perundang-undangan;

6) Dimungkinkan adanya bantuan dari pihak ketiga sebagai mediator atau konsiliator, meskipun bukan sebagai pemutus (judgement);

64 Adi Sulistiyono dan Muhammad Rustamaji, "Hukum Ekonomi sebagai Panglima", (Sidoarjo: Masmedia Buana Pustaka, 2009), hal. 139-140.

${ }^{65}$ Galanter menyebut keadilan distributif sebagai sentralisme hukum (legal centralism), yang memahami keadilan yang dicari adalah suatu produk yang dihasilkan, atau setidak-tidaknya didistribusikan secara eksklusif oleh negara. Perhatikan Marc Galanter. "Mega Law and Mega Lawyering in the Contemporary United States", dalam Robert Dingwall and Philip Lewis (ed.), "The Sociology of Profession", (London: The Macmillan, 1983), hal. 149.

${ }^{66}$ Interest based bargaining sebagaimana dijelaskan oleh Roger Fisher \& William Ury, "Getting to Yes, Negotiating an Agreement Without Giving in", Penguin Books, 1991,)adalah suatu teknik perundingan yang bertumpu pada kepentingan dan kebutuhan bukan mempertahankan posisi, yang bertujuan mencapai kesepakatan yang mencerminkan kepentingan dari kebutuhan para pihak yang bersengketa. Adapun Mas Achmad Santosa, Court Connected ADR in Indonesia, Urgensi dan Prasyarat Pengembangannya, Makalah, Disampaikan pada Seminar Nasional Court Connected-ADR, Departemen Kehakiman, Jakarta, 21 April 1999, hal. 5, menjelaskan bahwa penyelesaian sengketa dengan pola interest based berarti penyelesaian sengketa yang menggali kebutuhan dan kepentingan para pihak untuk kemudian dicarikan solusi yang dapat mencerminkan kepentingan para pihak tersebut. Pola interest based menekankan perlunya sikap positif melalui dialog untuk bersama-sama memecahkan masalah (joint problem solving). 
7) Tidak terbatas pada sengketa perdata, tapi juga sengketa pidana, maupun hukum internasional dan sengketa lainnya;

8) Yuridiksinya tidak terbatas di luar pengadilan, tapi dapat juga di dalam pengadilan;

9) Berorientasi pada pembinaan hubungan, kesinambungan atau menciptakan harmoni di masa depan;

10) Hasil keputusannya win-win solution, atau non-zero-sum. ${ }^{67}$

APS menurut UU No. 30 Tahun 1999 mengandung makna sebagai alternative to adjudication. ${ }^{68}$ Menurut Muhammad Syaifuddin, APS prosedurnya yang tunggal, tidak birokratis, cepat, dan biaya rendah, berdasarkan musyawarah untuk manfaat, dan ada kepastian yang dapat diterima oleh semua pihak yang bersengketa dibandingkan dengan penyelesaian sengketa di pengadilan. ${ }^{69}$ Selain itu, APS menurut Adi Sulistiyono dan Muhammad Rustamaji, lebih memanusiakan kembali harkat manusia dalam mengatasi sengketa yang timbul dari pada pengadilan. Bahkan APS secara umum dianggap lebih mampu mengatasi, menembus sekat-sekat ruang dan waktu yang disebabkan karena politik, sosial, budaya, agama, atau sengketa antarnegara, dan juga telah mampu menembus sekat tebal yang membentengi yuridiksi perkara pidana dan perkara perdata. ${ }^{70}$

\footnotetext{
${ }^{67}$ Non-zero-sum adalah istilah yang digunakan oleh Hugh Miall, Oliver Ramsbotham \& Tom Woodhouse,. "Resolusi Damai Konflik Kontemporer", (Jakarta: Rajawali Pers, 1999), hal. 10, yang berarti "Suatu keadaan di mana kedua belah pihak yang berperkara dapat memperoleh hasil".

${ }^{68}$ Suyud Margono, "ADR (Alternative Dispute Resolution) \& Arbitrase: Proses Pelembagaan dan Aspek Hukum", (Jakarta: Ghalia Indonesia, 2000), hal. 36, menjelaskan bahwa APS yang merupakan terjemahan dari istilah asing (Inggris), yaitu Alternatif Dispute Resolution, yang diartikan sebagai alternative to litigation dan alternative to adjudication, yang kedua pengertian itu menimbulkan implikasi makna yang berbeda. Alternative to litigation mempunyai implikasi makna seluruh penyelesaian sengketa di luar pengadilan, termasuk arbitrase, merupakan bagian dari APS. Sebaliknya, alternative to adjudication mempunyai impliksi makna APS dapat meliputi mekanisme penyelesaian sengketa yang bersifat konsensus atau kooperatif, seperti halnya negosiasi, mediasi, dan negosiasi.
}

${ }^{69}$ Muhammad Syaifuddin, "Hukum Paten: Analisis Paten dalam Perspektif Filsafat, Teori, dan Dogmatik Hukum Nasional dan Internasional", (Malang: Tunggal Mandiri Publishing, 2009), hal. 182. 
APS menurut Pasal 1 angka 1 UU No. 30 Tahun 1999 mencakup bentuk dan mekanisme hukum penyelesaian sengketa berupa negosiasi, ${ }^{71}$ mediasi, ${ }^{72}$ konsiliasi $^{73}$ atau cara lain yang dipilih oleh para pihak sesuai dengan undang-undang yang berlaku), ${ }^{74}$ yang merupakan refleksi dari asas kerukunan yang menghendaki penyelesaian sengketa secara musyawarah yang menekankan keseimbangan hak dan kewajiban para pihak yang bersengketa, sedangkan peradilan merupakan sarana terakhir.

\section{e. Nasionalisasi perusahaan modal asing diselesaikan melalui arbitrase, jika alternatif penyelesaian sengketa tidak berhasil}

\footnotetext{
${ }^{70}$ Adi Sulistiyono dan Muhammad Rustamaji. Op. Cit. hal. 134.
}

71 Negosiasi adalah suatu cara penyelesaian sengketa yang tidak terikat prosedur formal, bebas sesuai kehendak para pihak, tetapi berdasarkan prinsip itikad baik dan prinsip persamaan yang daya mengikatnya bergantung pada kepada maksud-maksud baik para pihak yang telah sepakat untuk bernegosiasi. Perhatikan Peter Behrens. "Alternative Methods of Dispute Settlement in International Economic Relations", dalam Ernst-Ulrich Petersmann and Gunther Jaenicke, "Adjudication of International Trade Dispute in International and National Ecomic Law”, (UP: Friborg, 1992), hal. 17. Perhatikan juga Huala Adolf, "Hukum Ekonomi Internasional: Suatu Pengantar", (Jakarta: PT RajaGrafindo Persada, 2003), hal. 254-255.

72 Ibid,, hal. 22. Mediasi adalah, suatu cara penyelesaian penyelesaian sengketa yang memanfaatkan bantuan aktif pihak ketiga sebagai mediator yang netral yang prosedurnya agak tidak resmi (informal), bebas sesuai kehendak para pihak. Fungsi utama mediator adalah mencari berbagai solusi (penyelesaian), mengidentifikasi hal-hal yang dapat disepakati para pihak serta membuat usulan yang dapat mengakhiri sengketa. Perhatikan Peter Behren, dan juga Huala Adolf, dalam Ibid., hal. $259-260$

73 Ibid., hal. 23-24. Konsiliasi adalah suatu cara penyelesaian sengketa yang prosedurnya lebih formal oleh pihak ketiga atau oleh suatu komisi konsiliasi yang dibentuk oleh para pihak. Komisi tersebut dapat yang sudah terlembaga atau ad hoc (temporer) yang berfungsi menetapkan persyaratan penyelesaian yang diterima oleh para pihak. Namun, putusannya tidak mengikat para pihak. Perhatikan Peter Behrens, dan juga Huala Adolf, dalam Ibid., hal. 260-261.

74 Cara lain yang dipilih oleh para pihak sesuai dengan UU yang berlaku, antara lain, penyelidikan atau penemuan fakta, adalah suatu upaya penyelesaian sengketa yang dilakukan oleh pihak ketiga yang sifatnya kurang formal yang lazimnya dilakukan jika negosiasi telah dilakukan dan tidak menghasilkan penyelesaian. Dengan penyelidikan ini, pihak ketiga akan berupaya memandang fakta-fakta sebenarnya dari semua sudut pandang guna menjelaskan kedudukan para pihak. Perhatikan Karl Josef Partsch, "Fact Finding and Inquiry", dalam R. Bernhardt (ed.), "Encyclopedia of Public International Law, Instalment 1", p. 61, dan juga Palitha T.B. Kohona, "The Regulation of International Economic Relations through Law", (The Netherlands: Martinus Nijhoff Publishers, 1985), hal. 162. 
Sengketa yang timbul berkaitan dengan bentuk, jumlah dan mekanisme pembayaran kompensasi kepada penanam modal asing yang perusahaan modal asingnya dinasionalisasi oleh Pemerintah Indonesia, dialihkan oleh Pasal 7 ayat (3) UU No. 25 Tahun 2007 untuk diselesaikan melalui arbitrase, jika APS tidak berhasil menyelesaikan sengketa dimaksud. Arbitrase adalah mekanisme penyelesaian sengketa dengan bantuan pihak ketiga yang netral dan bertindak sebagai "hakim" yang diberikan wewenang penuh oleh para pihak untuk menyelesaikan sengketa di antara mereka. Jadi, logis bahwa pihak ketiga itu mempunyai hak mengambil putusan (award) yang terakhir (final) dan bersifat mengikat (binding) serta mempunyai kekuatan hukum tetap. ${ }^{75}$

Arbitrase dipahami sebagai jawaban bagi penanam modal asing untuk menghindari akses negatif penyelesaian sengketa investasi, termasuk sengketa yang timbul sebagai akibat dari nasionalisasi perusahaan modal asing oleh Pemerintah Indonesia, melalui pengadilan di Indonesia. ${ }^{76}$ Menurut Ridwan Khairandy, Nandang Sutrisno, dan Jawahir Tontowi, penggunaan arbitrase sebagai cara menyelesaikan sengketa yang lazim di bidang bisnis, karena arbitrase dinilai lebih praktis, cepat, dan murah. Selain itu, arbitrase juga memiliki kelebihan atau keunggulan yang tidak dimiliki oleh peradilan umum, sebagai berikut:

1) Kebebasan, kepercayaan dan kemauan, yaitu memberikan kebebasan dan rasa aman kepada para pihak yang bersengketa terhadap keadaan tidak menentu dalam sistem hukum yang berbeda;

2) Keahlian arbiter, yaitu para arbiter adalah orang-orang yang ahli mengenai permasalahan yang disengketakan;

3) Cepat dan hemat biaya, yaitu proses pengambilan keputusannya cepat, tidak terlalu formal dan putusannya bersifat final and binding;

4) Konfidensial, yaitu arbitrase bersifat rahasia dan tertutup;

${ }^{75}$ Muhammad Syaifuddin. Op. Cit., hal. 173.

${ }^{76}$ Adi Sulistiyono, "Krisis Lembaga Peradilan di Indonesia", (Surakarta: UNS-Press, 2006), mengungkapkan tanpa "tedeng aling-aling" bahwa krisis dalam sistem peradilan Indonesia yang telah menyurutkan kepercayaan dan hilangnya kewibawaan pengadilan di mata masyarakat beberapa di antaranya disebabkan oleh: a) adanya tekanan dari pihak luar pada pengadilan dalam memutus perkara; b) jual beli vonis hakim; c) korupsi, kolusi, dan nepotisme di lingkungan pengadilan; d) puluhan ribu perkara yang menumpuk di Mahkamah Agung; dan e) Mahkamah Agung menjadi pasar jual beli perkara. 
5) Nonpreseden, artinya putusan arbitrase mengenai masalah yang sama mungkin saja berbeda dengan putusan arbitrase di masa datang;

6) Independen, artinya pemeriksaan oleh arbiter yang dipilih oleh kedua belah pihak, yang putusannya tidak dipengaruhi oleh pihak luar;

7) Kepekaan arbiter, artinya arbiter menerapkan hukum yang berlaku dalam menyelesaikan perkara dan lebih memberikan perhatian terhadap keiginan, realitas, dan praktik dagang para pihak. ${ }^{77}$

Penyelesaian sengketa melalui arbitrase dilakukan dalam kerangka hukum UU No. 30 Tahun 1999. Bersandar pada karakter yuridis arbitrase menurut UU No. 30 Tahun 1999, ${ }^{78}$ dapat dipahami bahwa untuk dapat menyelesaikan sengketa yang timbul sebagai akibat dari nasionalisasi perusahaan modal asing, maka Pemerintah Indonesia dan penanam modal asing yang perusahaan modal asingnya dinasionalisasi oleh Pemerintah Indonesia, harus membuat akta kompromis, yaitu suatu perjanjian arbitrase yang dibuat setelah timbulnya sengketa dimaksud, ${ }^{79}$ yang pengaturan hukumnya ada dalam UU No. 30 Tahun 1999 dan juga ada dalam Pasal II Konvensi New York 1958.

Lembaga Arbitrase internasional ${ }^{80}$ yang dapat dipilih oleh Pemerintah Indonesia dan penanam modal asing yang perusahaan modal

${ }^{77}$ Ridwan Khairandy, Nandang Sutrisno dan Jawahir Tontowi, "Pengantar Hukum Perdata Internasional Indonesia", (Yogyakarta: Gama Media, 1996), hal. 149-151.

${ }^{78}$ Karakter yuridis yang khas dari arbitrase menurut Pasal 1 angka 1 UU No. 30 Tahun 1999, yaitu: 1) dasar pengajuan sengketa ke arbitrase adalah perjanjian; 2) adanya kontroversi di antara para pihak yang diajukan kepada arbiter; 3) arbiter adalah pihak di luar badan peradilan umum; 4) arbiter diajukan oleh para pihak atau ditunjuk oleh badan tertentu; 5) arbiter melakukan pemeriksaan perkara; dan 6) arbiter memberikan putusan yang terakhir dan mengikat para pihak.

${ }^{79}$ Selain akta kompromis, perjanjian arbitrase juga dapat dibuat dalam bentuk pactum de compromittendo, yang dibuat oleh para pihak untuk menyelesaikan sengketa yang belum timbul pada saat perjanjian arbitrasenya dibuat oleh para pihak dimaksud, yang pengaturan hukumnya juga ada dalam UU No. 30 Tahun 1999 dan Pasal II Konvensi New York 1958.

${ }^{80}$ Arbitrase internasional lebih dipercaya dan dinilai lebih berkeadilan, berkepastian, dan berefisiensi daripada pengadilan bahkan arbitrase nasional di Indonesia. Ini berarti bahwa pengaturan hukum penyelesaian sengketa investasi di Indonesia (vide UU No. 25 Tahun 2007 jis. UU No. 30 Tahun 1999) itu telah mengandung karakter hukum yang sesuai dengan kehendak investor atau penanam modal asing dalam perspektif global. Perhatikan Muhammad Syaifuddin. 2009. Perspektif 
asingnya dinasionalisasi oleh Pemerintah Indonesia, antara lain, ialah: International Center for Settlement of Investment Dispute (ICSID) $)^{81}$ atau International Chamber of Commers (ICC) ${ }^{82}$ atau Arbitrase Centres Asian African Legal Consultatif Committee (AALCC). ${ }^{83}$ Indonesia sendiri telah meratifikasi United Nations Convention on the Recognition and Enforcement of Arbitral Award (Konvensi New York 1958) dengan Keputusan Presiden Nomor 34 Tahun 1981. Pasal 2 Konvensi New York 1958 memuat penegasan bahwa putusan arbitrase yang berada di luar yuridiksi suatu negara atau arbitrase internasional dapat dilakukan penegakan hukum.

Pengakuan hukum Indonesia terhadap putusan arbitrase internasional semakin diperkuat setelah berlakunya UU No. 30 Tahun 1999, khususnya dalam Bagian Kedua, Pasal 65 sampai dengan Pasal 69. Pasal 65 UU No. 30 Tahun 999 memberikan wewenang hanya kepada Pengadilan Negeri Jakarta Pusat untuk menangani masalah pengakuan dan pelaksanaan Putusan Arbitrase Internasional. Selanjutnya, Pasal 66 UU No. 30 Tahun 1999

Global Penyelesaian Sengketa Investasi di Indonesia, Makalah, Disampaikan pada Lokakarya Pengembangan Kemampuan Hakim, dengan Tema Membangun Komitmen Bersama dalam Rangka Penegakan Hukum di Bidang Ekonomi, dan Subtema Perspektif Global Penyelesaian Sengketa Investasi di Indonesia, Diselenggarakan oleh Komisi Yudisial Bekerja Sama dengan Pengadilan Tinggi Sumatera Selatan, pada 23 Juli, di Hotel Arya Duta, Palembang.

${ }^{81}$ Huala Adolf, Op. Cit., hal. 265. ICSID adalah badan yang dibentuk oleh Bank Dunia. Konvensi yang mendirikan badan ini, yaitu Konvensi CSID (Convention on the Settlement of Investment Dispute between States and Nationals of Other States), atau kadang-kadang disebut Konvensi Washington atau Konvensi Bank Dunia, ditandatangani di Washington D.C., 18 Maret 1965. Badan Arbitrase ICSID atau the Centre berkedudukan di Washington dan berafiliasi dengan Bank Dunia. Konvensi mulai berlaku pada 14 Oktober 1966, sebulan setelah 20 negara meratifikasinya.

${ }^{82}$ ICC adalah Kamar Dagang dan Industri Internasional yang berkedudukan di Paris, Perancis. Asosiasi dagang internasional ini memiliki badan penyelesaian sengketa dagang, yaitu Peradilan Arbitrase ICC (Court of Arbitration). Meskipun bermarkas di Paris, Perancis, sidang Arbitrase ICC dapat berlangsung di mana saja dan menerapkan hukum yang para pihak telah sepakati. Huala Adolf, "Dasar-dasar Hukum Kontrak Internasional", (Bandung: PT. Refika Aditama, 2008), hal. 179.

${ }^{83}$ Sudargo Gautama, Op. Cit., hal. 49 dan 51. Arbitrase Centres AALCC adalah pusat-pusat arbitrase regional yang didirikan oleh negara-negara Asia dan Afrika pada tahun 1977, yang berpusat di Kualalumpur, Malaysia dan Kairo, Mesir. ICSID yang berpusat di Washington telah menyetujui bahwa arbitrase-arbitrase yang diadakan di bawah CSID dari tahun 1966 yang diprakarsai oleh World Bank, dapat diadakan secara keseluruhan atau sebagian di pusat arbitrase AALCC di Kualalumpur. 
memuat persyaratan suatu putusan arbitrase internasional dapat memperoleh pengakuan dan dapat dilaksanakan di Indonesia. ${ }^{84}$

Permohonan pelaksanaan Putusan Arbitrase Internasional, menurut Pasal 67 ayat (1) UU No. 30 Tahun 1999, dilakukan setelah putusan tersebut diserahkan dan didaftarkan oleh arbiter atau kuasanya kepada Panitera Pengadilan Negeri Jakarta Pusat. Terhadap putusan Ketua Pengadilan Negeri Jakarta Pusat sebagaimana dimaksud dalam Pasal 66 huruf d UU No. 30 Tahun 1999 yang mengakui dan melaksanakan Putusan Arbitrase Internasional, tidak dapat diajukan banding atau kasasi. Kemudian, menurut Pasal 69 UU No. 30 Tahun 1999, untuk pelaksanaan eksekuatur dan sita eksekutorial tetap mengacu kepada ketentuan dalam Hukum Acara Perdata (vide Pasal $206 \mathrm{HIR} / \mathrm{RBg}$ ).

\section{Penutup}

Berdasarkan pembahasan sebagaimana diuraikan di atas, kajian hukum ini memperoleh tiga kesimpulan, yaitu: pertama, ide normatif pengaturan hukum nasionalisasi perusahaan modal asing dalam UU No. 25 Tahun 2007 adalah mewujudkan kedaulatan ekonomi dan politik Indonesia, untuk mempercepat pembangunan ekonomi nasional, yang mengedepankan potensi bangsa dan negara dengan tidak menutup diri pada masuk masuknya modal asing dalam rangka mewujudkan kesejahteraan rakyat Indonesia; kedua, ide normatif pengaturan hukum nasionalisasi perusahaan modal asing dalam UU No. 25 Tahun 2007 mempunyai relevansi dengan konsep Negara Hukum Kesejahteraan Pancasila yang membolehkan nasionalisasi perusahaan modal asing dimaksud, tetapi harus

\footnotetext{
${ }^{84}$ Persyaratan suatu putusan arbitrase internasional dapat memperoleh pengakuan dan dapat dilaksanakan di Indonesia menurut Pasal 66 UU No. 30 tahun 1999, adalah: (1) Putusan arbitrase internasional dijatuhkan oleh arbiter atau majelis arbitrase di suatu negara yang dengan negara Indonesia terikat perjanjian, baik secara bilateral maupun multilateral mengenai pengakuan dan pelaksanaan putusan arbitrase internasional; (2) Putusan arbitrase internasional tersebut menurut ketentuan hukum Indonesia termasuk dalam ruang lingkup hukum perdagangan; (3) Putusan arbitrase internasional yang dapat dilaksanakan di Indonesia adalah putusan arbitrase yang tidak bertentangan dengan ketertiban umum; (4) Putusan arbitrase internasional dapat dilaksanakan di Indonesia setelah memperoleh eksekuatur dari Ketua Pengadilan Negeri Jakarta Pusat; dan (5) Terhadap putusan arbitrase internasional yang salah satu pihaknya adalah negara Indonesia, hanya dapat dilaksanakan setelah memperoleh eksekuatur dari Mahkamah Agung RI yang selanjutnya dilimpahkan ke Pengadilan Negeri Jakarta Pusat.
} 
memenuhi persyaratan kondisional, persyaratan tujuan dan persyaratan prosedural, dalam rangka menegakkan kembali kedaulatan ekonomi dan kedaulatan politik, untuk mewujudkan kesejahteraan rakyat Indonesia dan menjunjung tinggi harkat dan martabat kemanusiaan manusia Indonesia sebagai makhluk Tuhan yang Maha Esa; dan ketiga, asas-asas hukum yang merefleksikan ide normatif pengaturan hukum nasionalisasi perusahaan modal asing adalah asas kepastian hukum, asas keterbukaan, asas akuntabilitas, asas perlakuan yang sama dan tidak membedakan asal, dan asas kemandirian, yang dikonkritisasi hukum dalam UU No. 25 Tahun 2007 jis. UU No. 30 Tahun 1999, yang membolehkan Pemerintah Indonesia menasionalisasi perusahaan modal asing, dengan persyaratan, yaitu: a. kepentingan negara menghendaki; b. berdasarkan undang-undang; c. disertai kompensasi sesuai dengan asas-asas hukum internasional; $d$. diselesaikan secara nonlitigasi dalam kerangka hukum alternatif penyelesaian sengketa; dan e. diselesaikan melalui arbitrase, jika alternatif penyelesaian sengketa tidak berhasil. 


\section{Daftar Pustaka}

\section{Buku}

Adolf, Huala. Aspek-aspek Negara dalam Hukum Internasional, Jakarta: PT. RajaGrafindo Persada, 1996.

- Hukum Ekonomi Internasional: Suatu Pengantar, Jakarta: PT. RajaGrafindo Persada, 2003.

. Perjanjian Penanaman Modal dalam Hukum Perdagangan Internasional (WTO), Jakarta: PT. RajaGrafindo Persada, 2004.

. Dasar-dasar Hukum Kontrak Internasional, Bandung: PT. Refika Aditama, 2008.

Adriaanse, P. Confiscation in Private International Law, The Hague: Martinus Nijhoff, 1956.

Almond, Gabriel A. Comparative Politics System, Process, and Policy. Boston: Little Brown and Company, 1978.

Asshiddiqie, Jimly. 2010. Konstitusi Ekonomi, PT. Kompas Media Nusantara, Jakarta.

Azhary. Negara Hukum Indonesia (Analisis Yuridis tentang Unsur-unsurnya), Jakarta: UI-Press, 1995.

Behrens, Peter. Alternative Methods of Dispute Settlement in International Economic Relations, dalam Ernst-Ulrich Petersmann and Gunther Jaenicke. Adjudication of International Trade Dispute in International and National Ecomic Law, Friborg U.P., 1992

Brittan, Sir Leon, Building on the Singapore Ministerial: Trade, Investment and Competition, dalam Jagdisc Bhagwati \& Mathias Hirsch (eds.). The Uruguay Round and Beyond, New York: Springer, Berlin, 1998.

Busroh, Abu Daud dan Abubakar Busro. Asas-asas Hukum Tata Negara, Jakarta: Ghalia Indonesia, 1991.

Capra, Fritjof. The Hidden Connections, Strategi Sistemik Melawan Kapitalisme Baru, Yogyakarta: Penerbit Jalasutra, 2004.

Friedman, S. Expropriation International Law, London: Stevens \& Sons Ltd., 1953. 
Galanter, Marc. Mega Law and Mega Lawyering in the Contemporary United States, dalam Robert Dingwall and Philip Lewis (ed.). The Sociology of Profession, London: The Macmillan, 1983.

Gautama, Sudargo. Indonesia dan Arbitrase Internasional, Bandung: Alumni, 1986.

Green, N.A. Maryan. International Law of Peace, London: Mac Donald and Evans, 1982.

Hadjon, Philipus M. Perlindungan Hukum bagi Rakyat Indonesia, Surabaya: Bina Ilmu, 1987.

Harjono, Dhaniswara K. Hukum Penanaman Modal: Tinjauan terhadap Pemberlakuan Undang-Undang Nomor 25 Tahun 2007 tentang Penanaman Modal, Jakarta: PT. RajaGrafindo Persada, 2007.

Harris, D.J. Cases and Materials on International Law, London: Sweet and Maxwell, 1983.

Jhamtani, Hira. WTO dan Penjajahan Kembali Dunia Ketiga, Penyunting Roem Topatimasang, Yogyakarta: INSISTPress, 2005.

Khairandy, Ridwan. Nandang Sutrisno dan Jawahir Tontowi. Pengantar Hukum Perdata Internasional Indonesia, Yogyakarta: Gama Media, 1996.

Kohona, Palitha T.B. Kohona. The Regulation of International Economic Relations through Law, The Netherlands: Martinus Nijhoff Publishers, 1985.

Kusumaatmadja, Mochtar. Pengantar Hukum Internasional, Bandung: Binacipta, 1982.

Mahadi. Falsafah Hukum suatu Pengantar, Bandung: Citra Aditya Bakti, 1989.

Margono, Suyud. ADR (Alternative Dispute Resolution) \& Arbitrase: Proses Pelembagaan dan Aspek Hukum, Jakarta: Ghalia Indonesia, 2000.

Miall, Hugh, Oliver Ramsbotham \& Tom Woodhouse. Resolusi Damai Konflik Kontemporer, Jakarta: Rajawali Pers, 1999.

Mustafa, Bachsan. Pokok-pokok Hukum Administrasi Negara, Bandung: Alumni, 1998.

O'Connell. D.P. International Law, London: Stevens and Sons, 1970.

Panjaitan, Hullman. Hukum Penanaman Modal Asing, Jakarta: Ind-Hill Co., 2003.

Shaw, Malcolm N. International Law, London: Butterworths, 1986. 
Soejadi. Pancasila sebagai Sumber Tertib Hukum Indonesia, Jakarta: Lukman Offset, 1999.

Soeprapto, Maria Farida Indrati. Ilmu Perundang-Undangan: Dasar dasar dan Pembentukannya, Yogyakarta: Penerbit Kanisius, 1998.

Somarajah, M. The Law of Investment, Cambridge: Cambridge U.P., 1994.

Sunandar, Taryana. Perkembangan Hukum Perdagangan Internasional dari GATT 1947 sampai Terbentuknya WTO, Jakarta: Badan Pembinaan Hukum Nasional Departemen Kehakiman, 1995-1996.

Sulistiyono, Adi. Krisis Lembaga Peradilan di Indonesia, Surakarta: UNS-Press, 2006.

dan Muhammad Rustamaji. Hukum Ekonomi sebagai Panglima, Sidoarjo: Masmedia Buana Pustaka, 2009.

Syaifuddin, Muhammad. Hukum Paten: Analisis Paten dalam Perspektif Filsafat, Teori, dan Dogmatik Hukum Nasional dan Internasional, Malang: Tunggal Mandiri Publishing, 2009.

Wargakusumah, Moh. Hasan, dkk. Perumusan Harmonisasi Hukum tentang Metodologi Harmonisasi Hukum, Jakarta: Badan Pembinaan Hukum Nasional Departemen Kehakiman, 1996-1997.

\section{Konstitusi dan Peraturan Hukum}

Undang-Undang Dasar Negara Republik Indonesia Tahun 1945.

Undang-Undang Nomor 86 Tahun 1958 tentang Nasionalisasi PerusahaanPerusahaan Milik Belanda.

Undang-Undang Nomor 1 Tahun 1967 tentang Penanaman Modal Asing.

Undang-Undang Nomor 8 Tahun 1995 tentang Pasar Modal.

Undang-Undang Nomor 30 Tahun 1999 tentang Arbitrase dan Alternatif Penyelesaian Sengketa.

Undang-Undang Nomor 19 Tahun 2003 tentang Badan Usaha Milik Negara.

Undang-Undang Nomor 25 Tahun 2007 tentang Penanaman Modal.

Undang-Undang Nomor 40 Tahun 2007 tentang Perseroan Terbatas. 


\section{Jurnal (Berkala IImiah), Makalah dan Naskah Akademik}

Burt, Eric M."Developing Countries and the Framework for Negotiations on Foreign Direct Investment in the World Trade Organization", 12:6 Am. U.J.Int'l.L \& Pol'y, 1997.

Geist, Michael A. 1995. "Toward a General Agreement on the Regulation of Foreign Direct Investment", 26 Law \& Pol'y Int'l Bus, 1995.

Ginting, Budiman. "Refleksi Historis Nasionalisasi Perusahaan Asing di Indonesia", Jurnal Equity, Vol. 12 No. 2, Agustus, 2007.

Rossen, Keith S. Rossen, dalam Fakultas Ekonomi Universitas Airlangga, "Jawaban dan Masukan RUU Penanaman Modal”, No. 1310/J.3.1.12/LL.2006, tanggal 21 September, 2006.

Santosa, Mas Achmad. "Court Connected ADR in Indonesia, Urgensi dan Prasyarat Pengembangannya", Makalah, Disampaikan pada Seminar Nasional Court Connected-ADR, Departemen Kehakiman, Jakarta, 21 April, 1999.

Seidl-Hohenveldern, I. 1986. "General Course on Public International Law", 198 Recueil des Cours 198, 1986.

Shihata, Ibrahim F.I. "Factors Influencing the Flow of Foreign Investement and the Relevance of a Multilateral Guarantee Scheme”, 21 Int'l. Law, 1987.

Simanjuntak, Djisman, dkk. 2006. "Naskah Akademik Rancangan Undang-Undang Penanaman Modal”, Badan Pembinaan Hukum Nasional-Departemen Hukum dan Hak Asasi Manusia, Jakarta, 2006.

Susilo, Agus Broto. "Dampak Yuridis, Pertimbangan Ekonomis dan Cakrawala Sosiologis Ratifikasi Agreement on Establishing the World Trade Organization oleh Indonesia", Majalah Hukum dan Pembangungan, No. 2 Tahun XXVI, 1996.

Syaifuddin, Muhammad. "Perspektif Global Penyelesaian Sengketa Investasi di Indonesia", Makalah disampaikan pada "Lokakarya Pengembangan Kemampuan Hakim", dengan Tema "Membangun Komitmen Bersama dalam Rangka Penegakan Hukum di Bidang Ekonomi", dan Subtema "Perspektif Global Penyelesaian Sengketa Investasi di Indonesia", Diselenggarakan oleh Komisi Yudisial Bekerja Sama dengan Pengadilan Tinggi Sumatera Selatan, pada 23 Juli, di Hotel Arya Duta, Palembang, 2009. 


\section{Ensiklopedia dan Surat Khabar}

Anonim. "Bank Asing Dominan, Negara Lain Lebih Ketat Mengatur Perbankan Asing”, Kompas, Jum'at. 15 Oktober, 2010.

Partsch, Karl Josef. "Fact Finding and Inquiry", dalam R. Bernhardt (ed.), Encyclopedia of Public International Law, Instalment 1, 1981. 